\title{
VÄIKE TEEJUHT \\ LÄTI PROOSA TERRITOORIUMIL
}

\author{
GUNTIS BERELIS
}

$\mathrm{K}$

üsimuse võiks sõnastada sootuks lihtsalt ja teatud määral isegi primitiivselt: kas on olemas mingi omaduste, eripärade või tunnuste kogum, millega saaks enam-vähem täpselt kirjeldada mõistet „nüüdisaegne läti proosa"? Liigse jutu ja pika teoretiseerimiseta tuleb niisama lihtsalt ja primitiivselt ka vastata: sellist omaduste, eripärade või tunnuste kogumit pole. Ei ole võimalik koostada nüüdisaegse läti proosa kaanonit. Pole täpselt defineeritavaid orientiire, peajoont ega ka lahtreid, kuhu autorid hõlpsalt ja mugavalt, selge süsteemi järgi ära paigutada. On autorid, kes kirjutavad nii erinevalt, justkui oleksid neid kujundanud täiesti erinevad kogemused ja kultuurid. Siiski võib kõnelda mõningatest esmapilgul raskesti märgatavatest laiaulatuslikest protsessidest ja nähtustest, mis eristavad XXI sajandi esimese aastakümne proosat XX sajandi üheksakümnendate proosast.

Põgus pilguheit lähiminevikku. XX sajandi 60., 70. ja 80. aastate proosat vaadates on pilt selgemast selgem. On „elavad klassikud” - Regīna Ezera, Zigmunds Skujiṇš, Marǵeris Zariṇš, Alberts Bels - ja on „taustakirjanikud”, kes võivad olla küll omapärased ja huvitavad, kuid kelle tekstid siiski jäävad kuskile kirjanduse tagaplaanile ega avalda proosa peajoonele praktiliselt mingit mõju. Sama oluline on see, et kõik need autorid esindavad kirjutuslaadi, mille aluseks on kas rohkem või vähem esile tungiv realismikood - arusaam, et sõna abil on võimalik maailma kirjeldada.

Kaheksakümnendate lõpus, eriti aga üheksakümnendail aastail muutus olukord kiiresti. Osaliselt võib see tuleneda sellest, et kirjandusse sisenes uus, äärmiselt võimekas põlvkond: kaheksakümnendate lõpus Gundega Repše (sündinud 1960), Andra Neiburga (1957), Guntis Berelis (1961), Rimants Ziedonis (1962), üheksakümnendail Nora Ikstena (1969), Jānis Einfelds (1967), Pauls Bankovskis (1973), Arvis Kolmanis (1959), veidi hiljem Inga Ābele (1972), Dace Rukšāne (1969) ja Laima Muktupāvela (1962). Siiski polnud asi vaid põlvkonnavahetuses - kirjanduse allhoovustes toimusid palju olulisemad muutused. Lihtsustades võiks öelda, et omal ajal erines Regīna Ezera Zigmunds Skujiņšist märksa vähem kui tänapäeval Nora Ikstena näiteks Jānis Einfeldsist või Inga Ābelest. Teisisõnu tekkis kirjanduses tohutu kirjutuslaadide mitmekesisus. Üheksakümnendail aastail oli kirjanduse raskuskese lühiproosal, mis muutus justkui polügooniks, kus hulljulgelt eksperimenteerida ja mitmesuguseid kirjutuslaade proovida. Suhteliselt lühikese ajavahemiku jooksul hoogustus kirjandusprotsessi dünaamika tublisti: kirjandus teisenes - muutus suhtumine nii maailma kui ka teksti, mis omakorda moonutas maailma ja teksti vahelisi suhteid. Kirjandus - ja kultuur üldse - muutus intellektuaalsete väärtuste kogumiks, millest vajaduse korral on võimalik midagi laenata ja enda tarbeks ära kasutada: selle asemel et näiteks Jānis Rainis, Aleksandrs Čaks või mõni teine klassik pjedestaalilt alla tõugata, leida hoo- 
pis võlusõna, mille abil need suure vaevaga mälestussammasteks muudetud isikud ellu äratada. Ja võimalik, et allutada omaenda kavatsustele. Polnud sellist realismi, mis oleks olnud teistest kirjutuslaadidest „reaalsem”, „objektiivsem” või „tõesem”; oli vaid realism, mida nii mõnigi otsustas trumbina ära kasutada. Osaliselt võib see muidugi tuleneda sellest, et nõukogudeaegne realism - ükspuha, kas täiendiga „sotsialistlik” või ilma selleta - oli suurel määral ideologiseeritud ning kaheksa- ja üheksakümnendate aastate noorte literaatide põlvkonnas kutsus see esile peaaegu reflektoorse vastumeelsuse realismikoodi suhtes üldse. Pigem tuleks siin siiski kõneleda millestki muust - kirjandusliku paradigma muutusest. Juuksekarva lõhki ajamata ning terminoloogilistesse vaidlustesse laskumata võiks öelda, et läti kirjanduses tekkis postmodernistlik paradigma. Just paradigmaatiliste nihete perioodidel ei orienteeru kirjandus mitte lugeja varustamisele enam-vähem kvaliteetse lugemisvaraga, vaid keskendub iseendale. Hoomata on pidevaid pingeid ja dissonantse, mängitakse mitmesuguste äärmustega, tekivad kohati täiesti sõgedad tekstid, nihutatakse paigast mägesid ja kaevatakse auke, millesse kukub enamjaolt augukaevaja ise, ja nii edasi. Ühesõnaga järjekordselt küsib kirjandus, kes ta selline on ja kelle jaoks on teda üldse tarvis. Postmodernism - see paistab olevat rõõmurohke kaos, mida korrastada pole võimalik ega ka vajalik. Kaos kultuuris on omakorda harva viljakas keskkond. See ei lase klassikalisel viisil esivanemate konte lutsutada, vaid sunnib igaüht tõmbama jõujooni, mida pidi seda korrastada.

XXI sajandi alguses tundus olukord stabiliseeruvat. Hiljutised debütandid, kes justkui väljastpoolt kirjandusse tulles 1990. aastail selle kihama panid, kvalifitseerusid „sissesaanult” ise ümber kirjanduse kujundajateks. Tuli välja, et kõik need ekstreemsed esteetikad, eksperimendid ning äärmused, mis veel üsna hiljuti lugejaid hullutasid ning kriitikuid lõksu ajasid, pole ei põrutavad ega aja ka hulluks. Igal autoril on lihtsalt talle orgaaniliselt omane poeetika. Ja kõige olulisemaks osutub see, et need mõnikord täiesti erinevad poeetikad võivad eksisteerida kõrvuti ilma omavahelise konfliktita, üritamata näidata teise suhtes oma üleolekut. Olukorda visualiseerides kujuneb umbes selline pilt: iga autor on piiristanud oma territooriumi, millelt ei püüagi nina välja pista. Need territooriumid piirnevad üksteisega, mõnikord isegi kattuvad osaliselt, teinekord aga asuvad üksteisest püüdmatus kauguses.

Samal ajal tekkis kirjandusse „vaikushetk”. Hakkas nappima üllatusi - ka piiriületaja ja professionaalse provotseerija koht näis olevat tühi. Proosamaastik, kui tahes mitmekesine see ka polnud, muutus peaaegu etteaimatavaks. Oli juba enam-vähem selge, mida võib oodata Ikstenalt, mida Repšelt, Ābelelt, Bankovskiselt. Isegi Einfelds, kes algusest peale on olnud kirjanduse piiridele päris lähedal või isegi neist väljas, hakkas kohati iseennast kordama. Äärmiselt harva vilksatas silmapiiril mõni uus autor, kusjuures enamasti kadus see pärast rohkem või vähem lootustandvat debüüti teab mis põhjusel kirjandusest. Juba tõsiseltvõetavamad kirjanikud, kellest osa vanuse järgi noorema põlvkonna hulka ei kuulu, tekkisid aastakümne teisel poolel: Māris Bērziṇš (sündinud 1962), Gundars Ignats (1981), Maira Asare (1960), Kristīne Ulberga (1979), Osvalds Zebris (1975), Inga Žolude (1984), Jānis Joṇevs (1980). Kuid vale oleks seda olukorda pidada paigalseisuks, rutiiniks, inertsuseks või muuks sääraseks. Ajalugu näitab, et sellised paradigmaatilised nihked korduvad umbes kord veerandsajandi jooksul. Nende vahele jääb aga aeg, mil kirjandus äsjased „avastused” heaks kiidab ja omaks võtab. 
Üllatus siiski oli, kui nii võib nimetada ligi aastakümne jagu kestnud protsessi, ja selle eest hoolitses autor, kellelt üllatusi ei oodatud ja kelle töid kõrgelt ei hinnatud - Aivars Kḷavis (snd 1953). Ta debüteeris juba 1970. aastail sotsialismiajastule omase noorsooproosaga, kuid taasiseseisvumise järel kadus pikaks ajaks nii Riiast kui ka kirjandusest ning hakkas tegelema talupidamisega. Tema romaanitsükkel „Viṇpus vārtiem” („Teispool väravaid”) koosneb neljast mahukast köitest: „Adiamindes āksts” („Adiaminde narr”, 2005), „R̄gas kuprītis” („Riia küürakas”, 2007), „Piesmietais karavīrs” („Pilgatud sõdur”, 2009) ja „Ceḷojošā cirka gūstekṇi” („Rändtsirkuse vangid”, 2012). ${ }^{1}$ Kümme aastat tööd ning ligi tuhat aastat ajalugu. Väga tinglikult võiks selle tsükli paigutada ajaloolise romaani žanri. „Ajalooline romaan” sellepärast, et romaanis on erilist tähelepanu pööratud ajajärgule XVIII kuni XX sajandini, põigates ka kaugemasse minevikku - XIII sajandisse, XV ja XVI sajandi vahetusse jm. „Tinglikult ajalooline romaan” sellepärast, et „Teispool väravaid” ületab kaugelt ajaloolise romaani žanri kanoonilised piirid ja on olemuselt unikaalne teos kogu läti kirjandusloos. Muuhulgas heidab autor pilgu ajaloosündmustele, millele seni ei ole tähelepanu pööranud ei kirjanikud ega ka ajaloolased ja mis on ajaloomälust justkui kustutatud, kuna mitmetel põhjustel on need igal ajal olnud ebamugavad nii saksa, vene kui ka läti ajaloolastele. Näiteks „Riia küürakas” on äärmiselt huvitav ja vaieldav tõlgendus XIX sajandi alguse sündmustest, „Pilgatud sõduris” kirjeldatakse mõningaid Lätis Teise maailmasõja ajal toimunud sündmusi, mida ideoloogilistel kaalutlustel ei puudutatud ei nõukogude ajal ega ka hiljem. „Rändtsirkuse vangidest” võib lugeda mõnevõrra liigjulget versiooni Läti Vabariigi presidendi Kārlis Ulmanise elust ja surmast.

Igas romaanis on üks keskne süžeeliin, mis on tavaliselt seotud mõne isikuga, kes kord kerkib esiplaanile, kord taandub taustale. Selle liiniga püüab autor kirjeldada ajastut. Näiteks „Riia küürakas” on tähelepanu keskmes Tomass Šulcs, kaupmees ja laevaehitaja, kes kogeb peaaegu kõike, mida XIX sajandil kogeda on võimalik. „Pilgatud sõduris” - punane kütt, hiljem tulihingeline kommunist Augusts Miḳelsons. Paralleelselt keskliiniga jooksevad kõigist romaanidest läbi minevikupildid, kus tegutsevad reaalsed ajaloolised isikud alates Wolter von Plettenbergist kuni Stalini ja Ulmaniseni välja. Lisaks neile poliitilistele liinidele on igas romaanis üks peatükk eraldatud kultuuriliinile, mida vastavalt esindavad ikoonilised läti kultuuritegelased: Garlieb Merkel, Läti hümni autor Baumaṇu Kārlis, Reinis Kaudzīte, Ojārs Vācietis. Kokkuvõttes manab autori fantaasia esile vägagi küsitavaid, kuid samal ajal elegantseid ajaloosündmuste käsitlusi. Näiteks Tomass Šulcsi isa on vanemapoolne seelikukütt Goethe, seevastu Stalini erilist vimma lätlaste vastu seletatakse sellega, et kodusõja ajal oli tal olnud ebameeldiv kogemus kokkupuutel hilisema Läti armee kolonelleitnandi Antons Kḷavega. Siiski pole tähtsaim mitte romaanides leiduv ajalooline materjal ega ka süžee või koloriitsed tegelased. Oluline on autori laiem kavatsus - püüda „võrku” kogu Läti ajalugu alates XIII sajandist. Iga episoodi, samuti iga tegelase mõte või vähemasti puhtkonstruktiivne tähendus romaani struktuuris avaneb alles kogu tsüklis tervikuna. See ei tähenda, et igat romaani ei võiks lugeda iseseisva teosena. See on võimalik - iga romaan on täielikult lõpetatud tekst, igal romaanil on raskuskese, mille

${ }^{1}$ Romaanitsükli „Teispool väravaid” eest pälvis Aivars Kḷavis 2012. aastal Balti Assamblee kirjanduspreemia. 
ümber koonduvad sündmused ja tegelased. Romaanid harmoneeruvad omavahel, peegelduvad üksteises ja jätkavad üksteist, samal ajal säilitades oma sõltumatuse. Paljud fragmendid, põiked, süžee pea- ja kõrvalharud, mitmete perekondade eelkäijate ja järeltulijate tohuvabohu põimuvad kokku esmapilgul raskesti hoomatavaks mustriks - autoril on tõepoolest õnnestunud luua „ruumiline” mulje ajaloost. Ajalugu pole enam „süžee”, st põhjuslike seoste rodu, ega isegi mitte labürint - vaid pigem läbimatu padrik. „Skeem on välja töötatud juba esimeses köites - sündmused kulgevad paralleelselt mitmes ajas, ja selle juurde jään järjepidevalt ka edaspidi. Seal on mingi konks, mulle tundub see väga orgaaniline - ühe sündmuse kaudu näen teist ja teises ajas. Aeg ei kulge lineaarselt. Ka inimene ei mõtle lineaarselt - ja minu jaoks on see tõepoolest orgaaniline, romaan ise ütleb ette, millest ja millistest aegadest kirjutada," kommenteerib autor ühes intervjuus. Inimene küll ei tunne ega mõtle lineaarselt, kuid see-eest on lineaarne teksti tajumise protsess, mis omakorda viib mõttele, et ka teksti loomine peab kindlasti olema lineaarne ja vastama lugemisprotsessile. Siiski eitab Kḷavis täielikult sellist stereotüüpi, mis on eriti iseloomulik just võib-olla kõige konservatiivsemale žanrile, ajaloolisele romaanile. Tsükkel ei ole üles ehitatud kui algpunktist lõpp-punkti kulgev jutustus, vaid pigem kui „mõttemaailm”, kus üheaegselt toimuvad lõputult paljude ajastute sündmused, ja võimalik, et selle maailma ülesehitamine on suguluses mõtete võrgustikuga, mis kujuneb lugeja teadvuses romaani lugemise järel.

Mastaabilt võrdväärne, kuigi stiililt pigem kammerlik on Gundega Repše triloogia „Smagais metāls” („Raskmetall”). Repše debüteeris kaheksakümnendate keskel. Alguses käsitleti teda kui „vihaste tüdrukute” põlvkonna esindajat - need olid naisprosaistid, kelle töödele oli iseloomulik sotsiaalkriitiline rõhuasetus, eetiline maksimalism, tugevam tahe vaadata, mis peitub sotsiaalrealismi lihvitud pealispinna all. „Vihaste tüdrukute” proosa rauges, kuid Repše looming ja tegevus jätkusid ning laienesid. Repše üheksakümnendate aastate proosat võib väga tinglikult käsitleda kui postmodernistlike paradigmade realiseerimist naiselikult emotsionaalsel ja mõnikord eksalteeritud viisil. Igal juhul on lühiproosateostele „Septiņi stāsti par mīlu” („Seitse pala armastusest”, 1992), „Šolaiku bestiārijs” („Nüüdisaegne bestiaarium”, 1994), romaanidele „Ēnu apokrifs” („Varju apokrüüf”, 1996), „Sarkans” („Punane”, 1998), „Íkstīte” („Pöial-Liisi”, 2000) ja hiljem ka romaanile „Bāreṇu nams” („Orbude varjupaik”, 2008) iseloomulik nii eksperimenteerimine mitmesuguste proosavormide ja -žanritega, sügavad teksti peidetud eksistentsiaalsed refleksioonid, kauged rännakud aegruumi avarustesse, tabavalt sotsiaalkriitilised tähelepanekud kui ka äärmiselt lakooniline ja emotsionaalselt pingne jutustamisviis. Teosed luuletaja Ojārs Vācietisest, kunstnikest Kurts Fridrihsonsist, Līga Purmalest ja Džemma Skulmest lähenevad pigem romaanižanrile kui dokumentaalkirjandusele - autor ei püüa klassikalise biograafi kombel „kõrvalseisjana" või „objektiivselt" vaadata ja hinnata kirjeldatava objekti isiksust ja loomingut, vaid nagu varemgi kujutada kirjanikke ja kunstnikke vastavalt nende elukäigule ja maailmatunnetusele, kaotamata siiski sidet reaalsete ajaloosündmustega.

Tõenäoliselt on loomeisiku jaoks olulisim võime end mitte korrata, mitte taastoota kunagisi „avastusi”, kui tahes mugav, ahvatlev ja tulemusi garanteeriv selline tegevus ka ei tunduks. Repšele on see omane - iga tema raa- 
mat on nii stiililt, intonatsioonilt kui ka teemalt erinev, samal ajal säilitades äärmiselt orgaanilise, teatud määral „naiseliku” ja kordumatult repšeliku poeetika. Nii Repše teosed kui ka kirjutised ajakirjanduses on alatasa esile kutsunud diskussioone, mõnikord ka õige teravat kriitikat (eriti meessoost kriitikutelt), sest tal on kombeks provotseerida ja šokeerida, ta ei karda puudutada avalikkuse ja läti kirjanduse jaoks ebatavalisi, kohati ka ebameeldivaid teemasid. Samasugune on Repše seni tähelepanuväärseim saavutus, romaanitsükkel, mis koosneb kolmest romaanist: „Alvas kliedziens” (Tinakarjatus”, 2002), „Vara rati” („Vaskvanker”, 2006), „Dzelzs apvārdošana” („Raua needmine”, 2011). Kogu tsükkel ühes köites pealkirjaga „Raskmetall” avaldati 2012. aastal.

Tsükli kolm romaani on täiesti erinevad: nende tegevus toimub erinevatel ajavahemikel, romaane ei ühenda ühised tegelased (nii ei vasta autor ka küsimusele, kas kangelannad - vastavalt Rugetta, Roze, Raina - on üks ja seesama isik või mitte), samuti erineb teoste stiil. Iga romaani keskmes on ühe naise saatus. "Tinakarjatuses” tuleb teismelisel tüdrukul Rugettal elada sotsialismis, mis ta sisuliselt murrab. „Vaskvankris” tõstab romaani keskne kangelanna Roze mässu kogu maailma vastu - nii endiselt sotsialistliku tegelikkuse kui ka ühiskonna pealesurutud olemisprintsiipide vastu. Kõige vastuolulisema ülesehitusega on romaan „Raua needmine”, mille tegevus toimub tänapäeval ja kus kangelanna on küll olemas, kuid teda pole kohal - ta ilmneb vaid iseenda ja teiste tekstides, märkustes, vestlustes. Kõik kolm romaani on loodud kollaažitehnikas ja balansseerivad kirjanduse piiridel: need koosnevad päevaraamatute, kirjade, dialoogide, märkuste fragmentidest. Siiski moodustavad äärmiselt erinevad elemendid ühtse pildi, mis kõneleb naise - konkreetse ja samal ajal üleüldise, võimalik et teatud määral isegi „müütilise” (kalduvust mütologiseerida kohtab igas Repše töös) - suhetest tegelikkusega mitme aastakümne pikkusel ajaperioodil. Neid naisi saab tõlgendada mitmeti - niisama mitmeti saab tõlgendada ka metalli metafoori: metall on kõva ja vastupidav, samas võib seda sepistada, painutada ja murda; metallist tehakse nii pille kui relvi; metall võib olla talumatult raske koorem, siiski on metalli abil võimalik transformeerida tegelikkust. Autor ei ütle põhimõtteliselt midagi lõpuni ega sõnasta oma eksistentsiaalseid mõtisklusi argielus kasutatavateks sügavmõttelisteks aforismideks, nii võivad lugeja mõtted vabalt uitama minna. Peaasjalikult räägib tsükkel „Raskmetall” inimese suhetest ajaga - katsetest allutada aega ja sellest, kuidas aeg allutab ja deformeerib inimest, katsetest rebida end lahti aja raudsest haardest ja võimetusest seda täielikult teha.

Nora Ikstena kaks tähelepanuväärsemat romaani on eesti lugejale tuttavad: „Dzīves svinēšana” („Elu pühitsus”, 1998)² ja „Jaunavas mācība” („Neitsi õpetus", 2001) ${ }^{3}$. Ikstena debüteeris üheksakümnendail lühiproosaga. Need polnud „tõelised” jutustused, vähemasti mitte traditsioonilise arusaama kohaselt. Ikstena lugudes tekst justkui tekib eikusagilt ja tihtipeale ka kaob peaaegu et iseenesest. Jutustuse keskel võib ilma mingi üleminekuta alata teine jutustus, tegelikkusest võib saada unenägu või illusioon, täpsemalt öeldes on lõhe tegelikkuse ja unenäo vahel nii väike, et seda pole mõtet mainidagi. Tegevus toimub tinglikus, kohati suisa dekadentlikult estetiseeritud, samas tuttavlikus miljöös. Universaalseid kategooriaid ega süsteeme pole või on need

2 Tlk Ita Saks, 2003.

${ }^{3}$ Tlk Kalev Kalkun, 2011. 
oma pealetükkivas korrektsuses muutunud nii koomiliselt enesekindlaks, et lihtsalt lükatakse kõrvale. Vahel tundub, et jutustus on tekkinud ühestainsast juhuslikult pähe tulnud fraasist või ekstravagantsest, õnnestunud metafoorist, mis on paisunud, mängides üha iseendaga ja otsides sõnade vahele peidetud tähendusi. See ei tähenda, nagu oleksid Ikstena lood laialivalguvad ja amorfsed - struktuur neil on, kuigi see ei meenuta kristallivõret või lineaarset sündmuste ja episoodide ahelat, küll aga näiteks vihma, tuult või midagi muud niisama muutlikku ja pidevas liikumises olevat. Metafooripits jääb alati lõpetamata - Ikstena visandab võimaliku tõlgendusvälja vaid ligikaudselt.

Romaanis „Elu pühitsus” on süžee umbes selline. Sureb Helēna ema Eleonora, kes juba aegsasti on kutsunud oma matustele seitse haruldaselt värvikat inimest, kellel kõigil on olnud tema elus oluline roll, ja neil kõigil tuleb tema haual lugeda mõni psalm. Eleonora maetakse kenasti maha, kuid ööl pärast matuseid jutustavad need seitse inimest oma mälestusi Eleonorast, see tähendab, lugude jutustamine - see ongi elu pühitsemine. See on ka kõik, mis romaanis kirjeldatud ühe ööpäeva jooksul toimub, kuigi arvukad unenäod ning jutustused unenägudest ja Eleonorast paisutavad romaani mõõtmed hiiglaslikuks. Eleonoraga seotud mälestustes uidatakse ajas ja ruumis ning võetakse ette rännakuid ka hoopis metafüüsilistesse kaugustesse. „Elu pühitsust” on võimalik käsitleda ka romaanina surmast. Sel juhul on tegemist ühe mõjukaima romaaniga surmast kogu läti kirjandusloos (tõe huvides tuleb lisada, et sääraseid romaane on väga vähe - ja tõik, et surm on läti kirjanduses nõnda harv külaline, küllap kinnitab, et kirjandus ise kardab surma nii meeleheitlikult, et pelgab seda isegi mainida).

Romaan „Neitsi õpetus” erineb „Elu pühitsusest” suuresti esiteks juba selle poolest, et autor on muutunud palju teravamaks, vahetumaks ja ehk ka agressiivsemaks. Vähemaks on jäänud barokset priiskamist. Täpsemalt öeldes on metafooripits alles jäänud, kuid see on muutunud funktsionaalsemaks. See on ka loomulik, kuna Ikstena võluvalt eneseküllastel metafooridel on mõte vaid terviklikul kujul ja nende mõte on ennekõike kehtestada autori kirjutuslaad. Kui romaani läbilugemise järel õnnestub segunevatest tekstikihtidest välja filtreerida süžee, siis näikse see olevat läti kirjanduses üsna klassikaline: XX sajand joonistatakse välja ühe pere naiste kolme põlvkonna (Ārija - Astrīda - Asnāte) olemise kaudu. Endalegi päriselt teadvustamata impulsi ajel suundub Asnāte sajandi lõpul kaugesse maanurka Draudavasse, mahajäetud majja - kohta, kust on pärit tema perekond: „Tüünes pimeduses, maailma urkas pääseb Asnāte hing tõeluse juurde. [---] Õpib veerima. Instinktide silpidest õpib ta kokku panema tunnete sõnu, moodustama mõistuse lauseid, et rääkida kogemuse keeles."4 See ongi romaani pealkirjas nimetatud neitsi õpetus. Vahepalaks sellele, mida Asnāte paari päeva jooksul kogeb ja meenutab, on Ārija ja Astrīda olemasolu. Eelmised põlvkonnad pole surnud, nad on ikka veel kohal: romaanis rõhutatakse korduvalt mõtet, et Asnāte tunneb enda taga „tõelisuse rida" - ja ainult selle rea kontekstis tunneb ka tema end tõelisena. Sealjuures ei avata nende kolme naise elulugu traditsioonilisel viisil, üksikasjalikult ja peenelt. Lood on omamoodi eksistentsiaalsed kontsentraadid (mis ühtivad romaani „Elu pühitsus” dekameronliku struktuuriga): lühikesed episoodid, milles eksistents on kui kokku tõmbunud lõputult väikesesse punkti ja äkit-

${ }^{4}$ N. Ikstena, Neitsi õpetus. Tlk Kalev Kalkun. - Loomingu Raamatukogu 2011, nr 13-14. Tallinn: SA Kultuurileht, lk 19. 
selt plahvatab, paisates igale poole valgustust. Ja siin võib autor lauale lüüa oma trumbi - kogu lühiproosast ja „Elu pühitsusest” saadud kogemuse. Leidub efektselt groteskseid pilte. Leidub Ikstena proosale nii tüüpilisi värvikaid tegelasi, kes pelgalt oma olemasoluga avavad tekstis uksi lõpmatusse: näiteks anatoomikumi valvur Abakuks, kelle repliigid tema omapärase ameti ja surma pideva läheduse taustal osutuvad erakordselt tabavaks. Sealsamas kõrval - rahumeelselt lüürilised, hooti meditatiivselt ähmased tegevuspaigad, sealhulgas hipodroom, mille ümber tegevus raskestisõnastataval põhjusel (lakkamatu ringis liikumine? hasartmängu osakaal?) koondub. Niisama iseloomulikud on visioonid ja unenäod. Leidub tekstifragmente, mis elegantselt kujutavad kogu olemasoleva üheaegsust, leidub realistlikke pilte, mis metafoorilises raamistikus omandavad erilise jõu, leidub lõputult palju muud. Pisike romaan osutub hämmastavalt mahukaks.

„Neitsi õpetus” taaselustab mõned ilmselged mõisted, mis selle juba ammu on ära teeninud. Milline enam-vähem tõsine kirjanik tänapäeval tihkaks ilma hirmujudinateta kasutada näiteks armastuse mõistet? Jutt pole sellest, et armastus oleks kuhugi kadunud, vaid sellest, et magedate lauljate armaada on muutnud selle popkornilaadseks olluseks, mis ka hästi karastunud organismil südame pahaks ajab. Ikstena on leidnud lihtsa ja elegantse väljapääsu. Neid ilmselgeid ja ometigi niivõrd olulisi eksistentsiaalseid mõisteid nimetatakse liivi keeles, mille oskajaid tänapäeva Lätis on vaid käputäis. Ka edasi vilksatavad liivi keeles lihtsad asjad: „loomine”, „sinu tahtmine sündigu”, ,jumalaga”, „ma olen veel elus”, „mul on hirm”, „mu elu on väga ilus” ja muu seesugune. Sealjuures ei esine liivi keel kaugeltki mitte dekoratiivse etnograafilise suveniirina. Liivi keel - see on surev, unarusse jäetud, elujõuetuks tehtud keel; põhimõtteliselt on see vaid keele vari. Romaanis kõlab liivi keel lindude häälitsustes, unenägudes, visioonides. See ei tähenda, nagu sureksid ka need mõisted. Kirjanduses on surm üks võimsamaid metafoore (mida Ikstena suurepäraselt teadvustab, juhatades elu pühitsuse sisse Eleonora surmaga); veelgi võimsam on see siis, kui sureb - või ka balansseerib olemise ja mitte olemise vahel - keel. Surma kohalolu annab elule eriti jõulise impulsi.

Ikstenal on ilmunud ka mitmeid tinglikult eluloolisi teoseid: india tantsude tantsijannast Vija Vētrast, luuletaja Māra Zālītest, prosaist Regīna Ezerast. Sarnaselt Repšega läheneb Ikstena nendes teostes pigem proosale kui dokumentaalkirjandusele. Eriti iseloomulik on see teosele "Vīrs zilajā lietusmētelīt̄̄” („Sinise vihmamantliga mees”, 2011), mis jutustab tema suhetest prosaisti, James Joyce’i „Ulyssese” tõlkija ja keelevirtuoosi Dzintars Sodumsiga (pealkirjas nimetatud sinise vihmamantliga mees, kelle varjunimi romaanis on Tebe), kes suurema osa oma elust elas USA-s ja kelle Ikstena elu lõpus „koju tõi”, st toimetas vana ja haige meistri Lätti, majutas teda oma kodus ja lasi rahulikult surma oodata. Siiski pole see lugu Ikstena ja Sodumsi suhetest. Täpsemalt öeldes on lugusid mitu. Esiteks noorest kirjanikust, keda romaanis nimetatakse Tüdrukukeseks (Meitina), täpsemalt sellest, kuidas noor kirjanik adub, mis on kirjandus. Edasi, lugu väga vanast kirjanikust. Kuigi teoses leidub dramaatilisi ja traagilisi rõhuasetusi napilt ning need on justkui summutatud, on lugu hirmuäratav - maailmast lahtiütlemisest, askeesist, arulagedusest või rumalusest, kuidas võtta. Tõenäoliselt ei saa Sodums teiste kirjanikega võistelda ei avaldatud teoste hulgas ega ka kuulsuses, kuid pole palju neid, kes oleksid läti keelest ja kirjandusest mõelnud niivõrd pika- 
ajaliselt ja intensiivselt kui tema, olgugi et lõpptulemus pole kõige säravam: tuleb välja, et peale Tüdrukukese pole kellelgi teisel vaja ei Sodumsi teoseid, tema mõtteavaldusi ega ka teda ennast (väeti Sodumsi üksilduse pildid on tõepoolest jahmatavad). Sodums püüab aastakümneid „elada keeles, mitte kujutlustes või oletustes keele kohta”, kuniks säärasest „keeles elamisest” juba iseenesest saab tohutu väärtus. Kolmas lugu on kõige olulisem, keerulisem ja mitmekihilisem - lugu juhuste rodust, mis nad kokku toob, õigemini sellest, et need juhused pole üldse mitte juhuslikud. Kunst saab alguse hetkel, mil lugeja hakkab uskuma, et juhuslik on seaduspärane. Sel hetkel kaotab Sodums päris kirjaniku piirjooned, niisamuti kaugeneb Tüdrukuke Ikstenast, kuid mõlemad elutsevad mingites eeterlikes, mütoloogilistes, kirjanduslikes, metafoorsetes või kes teab veel millistes sfäärides. See moodustabki teose peatelje, millele on allutatud viimne kui detail. Tebe ei pea üldsegi mitte surema, isegi selleks, et temast saaks mütoloogiline kuju, on vaja vähe - aastakümneid „elada keeles”. Veel on esindatud mütoloogilised sfäärid, kus elutsevad nii Homerose Odysseus, Joyce’i Leopold Bloom („Ulysses”) kui ka lätindatud „Uliss”. Et aga reaalsus kaotaks argipäeva piirjooned ja muutuks müüdiks, mis omakorda oleks võimeline muutma reaalsust, on vajalik veel üks koostisosa - keegi peab müüti jutustama. Just seda teebki Ikstena.

Inga Ābele kirjutab proosat ja luulet, lavastatud on ka mitmeid tema näidendeid. Juba Ābele lühiproosa - jutukogumikud „Akas māja” („Kaevumaja”, 1999) ja „Sniega laika piezīmes” („Lumeaja märkmed”, 2004) - näitab, et mõne jutu jaoks jäävad sellele eraldatud leheküljed napiks. Ābele esimene romaan „Uguns nemodina” („Tuli ei ärata”, 2001) sarnaneb pika jutuga, mis on keskset liini jõuliselt uute detailide ja arendustega täiendades liiga pikaks venitatud. „Paisums” („Tõus”, 2008)5 on klassikalise modernismi vaimus konstrueeritud romaan, kui praegusel ajal oleks jutumärke kasutamata võimalik öelda, mis on päris romaan ja mis üldse on romaan. Kui oleks tarvis süžeed ümber jutustada (kohe aga tuleks vastu puigelda, et Ābele tööde süžeid, hoidku jumal, ei tohi mingil juhul ümber jutustada, kuna sel juhul ei jääks tema tekstidest just palju järele), siis näeks see välja umbes säärane: kaheksakümnendate ja üheksakümnendate aastate vahetusel abiellub nooruke Ieva maamehest töörügaja, põhjaliku Andrejsiga. Ievat ei huvita vähimalgi moel oma nurgakese, oma pesapaiga eest hoolitsemine, sestap hakkab ta vaatama naabri Akselsi poole ja hülgab Andrejsi. Järgneb boheemielu metropolis, Akselsist saab tavaline narkomaan, kuid siis laseb Andrejs Akselsi maha ja satub trellide taha. Loos on oma koht veel Ieva ema elul ja surmal, Ieva nooruse läbielamistel Gotlandil ja Stockholmis, tema ja Andrejse tütrel Montal, Ieva tublisti mõistlikumal vennal ja nii mõnelgi teisel. Ühesõnaga hauakoledused ja mitte proosa. Pärast sellist ümberjutustust kerkib silme ette hirmus pilt: Inga Ābelele pakub rahuldust roosa (värskelt lastud vere värvi) melodramaatilise vahu kloppimine.

Loomulikult tõstab kogu asja kõrgemale tasemele romaani keeruline vorm ja ennekõike see, et „Tõusu” süžee kulgeb tagurpidi: romaan algab Ieva ema surmaga tänapäeval, lõpeb aga ajas enam kui kolmkümmend aastat tagasi - Ieva sündimisega. Puhttehnilised kirjutamisvõtted hakkavad ajaga manipuleerima: siin-seal mahutab lühike ajavahemik enesesse olemise põhjatuid sügavikke, kohati aga hüpatakse kergelt üle aastate ja aastakümnete. Need

${ }^{5}$ Romaani „Tõus” eest pälvis Inga Ābele 2010. aastal Balti Assamblee kirjanduspreemia. 
täiuseni väljatöötatud episoodid on nõnda kirevad, et neid pole tarvis laiendada täiendavate detailide ega ajastupiltidega. Siiski on asi veel keerulisem. Romaan mitte ainult ei kulge lõpust algusesse, vaid alustab kõigist otstest üheaegselt - algusest, lõpust, keskelt, ka kõigi asjaosaliste vaatepunktidest, ja alles eelviimases peatükis „Üheksakümnendad” („Devin̨desmitie”) sulanduvad arvukad fragmendid lõpuks ühtseks pildiks (sealhulgas ilmneb, et Akselsi tapmise põhjused pole sugugi nii triviaalsed, kui esmapilgul tunduda võis). Siiski on need puhttehnilised knihvid, mida Ābele valdab suurepäraselt. Võimalik, et romaani sünge poeetika üks võti peitub peatükis „Andrejse religioon” („Andreja religija”), milles Andrejs loeb vanglas kättesattunud vanakreeka müütide ümberjutustust. Loomulikult otsib Andrejs vanakreeka müütidest paralleele oma eluga, talle meeldivad väga ajad, „mil kedagi polnud veel teise pattude eest risti löödud ega keegi teise eest lunastatud saanud”, ja Zeusi ees on ta lausa nõus mütsi maha võtma („see poiss oli nahka pistnud oma esimese naise" - pole vaja kaua mõelda, miks Andrejsele Zeus nii väga meeldib). Siinkohal tuleks taas rõhutada autori tehnilist meisterlikkust. Harva suudab kirjanik säärasel juhul vastu panna kiusatusele oma teosega illustreerida/muuta/ täiendada mõnda vanakreeka müüti, kuna intertekstuaalsusel on looma jõud - kui ise hakkama ei saa, tuleb alati appi Herakles või Odysseus. „Tõusus” pole kippu ega kõppu pealetükkivatest analoogiatest ega kokkulangevustest, ja siiski tulevad romaani lugemise ajal alalõpmata meelde need üksnes põgusalt käsitletud jumalate veretööd ja -patud. Kerkib küsimus: miks need üleüldse autorile vajalikud olid? Kreeklased inimestasid oma jumalaid: neile omistati samu ihasid ja nõrkusi mis inimeselgi, ainult et hüpertrofeerunult, ülivõrdes. Ābele läheb vastupidist teed - ta tõstab oma tegelased nende arhetüüpsete kujude tasemele. Muistsete aegade mütoloogiline draama kantakse üle tänapäeva maailma. Asjata ei loe Ieva ühel hetkel religiooniuurija Roberts Mūksi raamatut, mis käsitleb olemise lakkamatuid käänakuid ja igavest tagasitulekut. Müüdis pole olulised tegevuse tagajärjed, tähtis on vaid tegevuse mõte tegijale endale; kui on olemas impulss, tuleb see kindlasti realiseerida, mõtlemata sellele, milliseid muutusi see maailma toob. Just sellistest printsiipidest juhinduvad ka Ābele tegelased - kui midagi teha, siis niisama monumentaalselt kui jumaladki. Nad on monumentaalsed isegi oma rumaluses ja mõtlematuses. Ābelele on omane harvaesinev oskus hoomata neid eksistentsiaalseid kuristikke, mis asuvad argiolemise pealispinna all. „Tõusu” võib õige lühidalt iseloomustada paari tsitaadiga: „Vangistatud. Ellu vangistatud”; „... ühe õnneliku elu jaoks on elu liiga pikk”.

Inga Žolude tuli kirjandusse hoogsalt ja edukalt romaaniga „Silta zeme” („Soe maa”, 2008). Esialgu ajab pisut segadusse romaani tegevuse eriline keskkond, aeg, tegelaskond: peaaegu eikusagil, eikunagi ja eikeegi. Tegevuse aega ei täpsustata, ainult ligikaudu aimub, et see võiks toimuda väga tinglikus kaasajas. Koht - Aafrika, Istanbul, Peterburi, Itaalia -, kus hulguvad tegelased, on vaid tühi sõna, mida mõnikord ehitakse neegrite, mošeede, õlipuude, kuldsete kirikukuplite või muu taolise „koloriidiga”, ainuüksi Pariis on ära teeninud kombitavama kontuuri, mis küll piirdub Louvre'i ja Eiffeli torni mainimisega. Ka tegelasi ei seo ükski konkreetsus, ei keel ega ka sugu. Kui abort tehtaks Danielsile (kelle vaatepunktist sisemonoloogi laadis jutustus enamjaolt lähtub) või kui tema õde Nellijat õnnistataks mõningate meessoo omadustega, ei muutuks romaanis palju - ja ei tähenda midagi, et praegu teeb aborti Nellija, 
kuid naisi paneb Daniels. Tundub, et säärane „eikusagil ja eikunagi”-taktika on vajalik olnud kaunis triviaalsetel kaalutlustel - rõhutamaks, et tänapäeva inimene on kaotanud võime samastuda konkreetsete ruumi- ja ajapunktidega (minu meelest on see antropoloogide õhust võetud oletus, mida moodsate teooriate abil edukalt turustatakse) ja seetõttu vähemalt osaliselt ilma jäänud oma olemusest ning muutunud täiesti isiksuseta, meduusilaadseks sõnamassiks. Lõppude lõpuks pole küsimusel „kus ja millal?” vähemasti tegelaste vaatepunktist ja romaani kontekstis mitte mingisugust mõtet, need on vaid taustadetailid, olulisim toimub tegelaste mõtteis, kujutlusis, unenägudes, visioonides. Teoses „Soe maa” elunevad kujuteldamatult infantiilsed olendid, kes sealjuures oma infantiilsust teadvustavad ja oma kõlbmatusest ja eikuhugi sobimatusest pideva rahulduse saavad. Juba alguses kuulutatakse sümboolselt, et „tunneli lõpus on vaid pimedus”, kuid Daniels jätkab: „Me oleme kasutud inimesed, me pole loodud mõtlema mitte tulevikust, vaid iseendast. Mingisugused asotsiaalsed olendid, kes alalõpmata end taastoodavad, justkui oleksime nõnda väärtuslikud, et meil on lubatud jääda ükskõikseks selle maailmanurga vastu, kuhu me välja jõuame. Justkui maailmakord meid ei puudutaks, ja niipea kui see hakkab meid mõjutama, võiksime ära sõita teise kohta, mis teeb meid surematuks.” Või: „Me ei saa maailmale midagi anda, kuna meil pole juuri, pole tähendust, pole mõtet midagi luua ega jäädvustada, kuna peagi hülgame kasutatu. Milleks on meiesugustele antud aeg?" Ja nii edasi. Kõrvu Danielsi halamise ja freudistlike viguritega leidub hoopis teist laadi, hämmastavalt muljetavaldavaid proosastseene, näiteks Danielsi omapärased suhted piimaga. On ka mõni süžeeline kaunistus, näiteks koomiline episood, kus Daniels põrkab Peterburis kokku omaenda kunagise ja tulevase ning oma isa praeguse ja samuti tulevase kallima Vū ning õe kallima, neeger Jošīga. Sealjuures on isa, et säästa pisut raha ja üleüldse teha elu väheke kergemaks, üürinud Vūle ja Još̄le korteri. Pärast „Sooja maad” on Žolude avaldanud jutukogumiku „Mierinājums Ādama kokam” („Lohutus Aadama puule”, 2010), milles autor pakub välja niivõrd erinevaid süžeid ja kirjutuslaade, et teatud määral võiks kogumikku vaadata kaasaegse lühiproosa võimaluste entsüklopeediana, ja romaani „Sarkanie bērni” („Punased lapsed”, 2012), milles võib märgata maagilise realismi mõjusid.

Jānis Einfelds on läti kirjanduses peaaegu professionaalne provokaator ja piiriületaja. Mida iganes ta ka ei kirjutaks, on isegi kõige tundlikuma ja maailmakultuuris erudeerituima lugeja esimene küsimus umbes selline: „Kurat võtku, kas Einfelds teeb meid lolliks või on ta ise loll? Mis see on, mida ta kirjutanud on, ja mis seos on sel kirjandusega, ükskõik, kui kõrge või madalaga?" Einfeldsi proosa asub juba alates tema debüüdist, lühiproosa kogumikust „Mēness bērns” („Kuu laps”, 1995), väljaspool läti kirjanduse kogemusala, sealjuures lööb ta igas raamatus käega ka iseenda kogemusele, mille on omandanud eelmistes raamatutes, ja justkui hakkab kirjutama nullpunktist. Alguses näikse tema proosa olevat sarnane Nora Ikstena lugudega: keelelised metafoorid, mis üha iseendaga mängivad, tekitades mõnikord barokselt kirevaid, mõnikord õige kargeid ja veriseid (autor kuulub siiski meessoo hulka), kuid kindlasti mitte igapäevaselt kasutuskõlblikke pitse. Einfeldsile on omane tohutu keskendumine igale fraasile: tavaliselt sünnib metafoor lause alul, kuid punkt on sellele juba hauakiviks. Ka semantikas toimub isemoodi nihe: sõna mõisteväljad mitte ei haaku omavahel, vaid puutuvad üksnes põ- 
gusalt kokku; sõna pole enam liikumatu tellis keelemüüris - tekib pinge sõna tavapärase tähenduse ja tähenduse vahel, mille sõnale on usaldanud Einfelds; sõna elavneb ja justkui sünnib uuesti. Iga lugu moodustab uduse ja kaootilise metafooripilve. Kirjanduses kehtivad alati kirjutamata mängureeglid: mis on kirjandus, mis pole, mida tohib teha, mida mitte jne. Pärast Einfeldsi tekstide avaldamist on paljust keelatust saanud lubatu. Teisisõnu on Einfeldsi proosa tõestanud, et see, mida me veel üsna hiljuti pidasime kirjanduses sobimatuks, sündsusetuks ja ehk ka võimatuks, on nüüd nii sobilik, sünnis kui ka võimalik. Einfelds on maksimalist - oma poeetika, oma kirjutuslaadi eripära viib ta äärmusteni, balansseerides järjepidevalt piiril, mis eristab kirjandusteksti loetamatust ja arusaamatust sõnapudrust.

Einfeldsi lühiproosas püsibki kõik arusaadava ja arusaamatu, mõtestatuse ja mõttetuse piiril. Samm ühele poole - õudus, teisele poole - imal selgus. Ohtlik mäng - niipea kui mõõdutunne vähegi kaob, libiseb metafoor ühele või teisele poole ja haarab kaasa kogu kupatuse. Romaanis „Cūku grāmata” (,Sigade raamat”, 1996) lõi Einfelds täiesti mõttetu maailma, kus elutsevad ainuüksi sead oma seamütoloogia, seaelu, seaprobleemidega, kusjuures see ei ole allegooria. Einfeldsi sead ei asenda inimsugu ega näita, kuivõrd väär on sea moodi elamine - nad lihtsalt elavad oma searütmis. Romaan „Veči” („Vanakesed”, 1999) on tõenäoliselt kõige eemaletõukavam ja samas kõige tujutõstvam romaan kogu läti kirjandusloos. „Vanakesed” labastab kõike ja ei midagi. Kõikjal mädaneb, hallitab, haiseb miski. Ümberringi on vaid tatt, roe, ussid, lihakärbsed. Alatasa on keegi purjus, keegi oksendab, keegi peksab kedagi, kuseb kellegi peale või kustakse tema enda peale. Kõik teevad kõige mõttetumaid asju nagu vanades komöödiates või kaasaegsetes seriaalides, sealjuures kroonib autor romaani patoloogiliselt õnneliku lõpuga - kahekordsete pulmadega. Maailm on pilgeni täis degenerante ja idioote, kes räägivad ja käituvad vastavalt oma mõistuse arengutasemele. Seda kõike 180 lehekülje jagu. Autor on eemaletõukavuse, rumaluse ja vastikuse paisutanud kogu maailma suuruseks ning loonud tõepoolest muljetavaldava pildi kosmilisest prügikastist.

Einfeldsi kolmas romaan „Palaidnis” („Marakratt”, 2007) on taas murdepunkt tema loomingus: monumentaalne postapokalüptiline maastik peaaegu et küberpungi laadis. Agulid, mandunud, allakäinud inimesed, kes kõige hullemaid mõttetusi võtavad (ja sooritavad) kui midagi loomulikku. On olemas kaks väga teravalt vastanduvat kihti - eliit ja kaltsakad. Toimub orjakaubandus, kus rikkuritele müüakse kaltsakate lapsi, kellega hiljem koeri toidetakse. Aukohal on gladiaatorite võitlused. Kuigi „[v]iimased kannibalid meie rajoonis lasi politsei maha juba kolme aasta eest”, on inimliha degusteerimine siiski samuti au sees. On ka noorukite banded, üksikud kõrilõikajad, maniakid, mingisugused mõistetamatud sektandid, kes kooskõlas oma mõistetamatu olemusega (ja Einfeldsi proosa spetsiifikaga) tegutsevad täiesti arusaamatult. Romaani alguses vilksatavad isegi korraks postapokalüptiliste fantaasiate kõige klassikalisemad aksessuaarid - inimesi ründavad rotid. Tõsi küll, pakkunud efektseid süžeelisi murranguid ja elajalikku närvikõdi, kaovad rotid peagi igaveseks. Sellegagi tuleb leppida, kuna ka see kuulub Einfeldsi spetsiifikasse: hulk süžeid, tegelasi, metafoore tema proosas ilmub, areneb, mõnikord isegi elab läbi kulminatsiooni, kuid siis lihtsalt haihtub; jääb vaid mälestus ja ehk ka kerge pahameel kasutamata jäänud võimaluste pärast. Umbes säärases maailmas elama on autor määranud romaani pealkirjas mainitud marakrati 
- poisikese, kes kuulub kaltsakate kategooriasse ja tegeleb jäätiseäriga, kuigi oma olemuselt on ta üsna tore ja arukas poiss, sealjuures oskab hästi vastanduda maailma mõttetustele. Ta röövitakse, pannakse vangi, teda nuumatakse, poiss põgeneb, hiljem hakkab gladiaatoriks jne - detaile pole mõtet ümber jutustada, kuna Einfeldsile omaselt on süžee pisut ebaloogiline ja kohati hoopis arusaamatu. Paralleelselt marakrati ebaõnnega rullub lahti lugu politseiinspektor Boikost, kes hoopis omapärasel viisil, kuid tõsiselt ja ausalt - ja sestap ka edutult - püüab ellu viia väga kummalisi seadusepügalaid. Inspektor Boiko on politseiromaanide traditsioonist pärinev hall, argine, pisut koomiline, elust ja arvukatest kohustustest kurnatud tüüp, kes püüab võidelda maailmaga. Boiko surmast saab ainuke särav - see-eest rabavalt särav - hetk tema eluloos. Ja siis algab - miski. Mis? Sellele küsimusele on raske vastata, kuna Einfeldsil on kombeks alatasa väljuda kirjanduse harjumuspäraselt territooriumilt. Miski igas mõttes silmapaistev. Ehk algab „tõeline romaan”. Peatükke, kus gladiaatorit ei naelutata otsekohe risti, vaid temaga diskuteeritakse haaravalt kõiksuguste teoloogiliste ja lihtsalt loogikaprobleemide üle, võiks ehk veel käsitleda puhtalt einfeldsliku ilutsemisena. Süžeeliinid hargnevad, tegelased paljunevad hoogsalt. Niisama hoogsalt ja pika jututa saadetakse kõik, sealhulgas marakratt, manalasse (ma tõepoolest ei mäleta teist romaani, kus autor oleks niivõrd rõõmsalt tapnud absoluutselt kõik kesksed tegelased), mis, tuleb välja, polegi manala. Palju toimub ka peaaegu sürreaalseid sündmusi: oma koht maailma hierarhias on libahuntidel, lõvipeadel, komeedil, Püha Vaimu kloostri saadikuil ja paljudel teistel. Romaani esimeses osas pedantselt kokku pandud maailm rebeneb igast õmblusest valla, ärgitades nii mõtiskelu teemal „postapokalüptilise maailma apokalüpsis”. Apokalüpsis tõepoolest toimub, kuigi tuleb lisada, et see on tüüpiliselt einfeldsilik apokalüpsis, st tekst sööstab loogilisele mõistusele raskesti ligipääsetavatesse metafoorsetesse kõrgustesse.

Artikli alguses sai öeldud, et on raske tajuda läti nüüdisproosa jõujooni või lahtreid, kuhu autorid hõlpsalt ja mugavalt, selge süsteemi järgi ära paigutada. Üks protsess äratab siiski tähelepanu ka ilma igasuguse analüütilise optikata - realismikoodi rehabiliteerimine. Sajandi esimesel kümnendil püüdsid prosaistid põgeneda reaalsusest metafoorsetesse kõrgustesse või eksistentsiaalsetesse sügavikesse, praegu omakorda uitavad nad neis metafoorsetes kõrgustes ja eksistentsiaalsetes sügavikes, et lõppude lõpuks maapinnale naasta. Sealjuures toimub sama protsess nii kunagiste äärmuslaste kui ka viimaste aastate debütantide proosas. Kõige veenvamalt näitab seda Nora Ikstena proosa - nii terav ja samal ajal emotsionaalne romaan „Sinise vihmamantliga mees” kui ka jutukogumik „Dzīves stāsti” („Elulood”, 2004), mille pealkirigi on sümptomaatiline: alustanud „Pisiasjade ja lõbustustega” („Nieki un izpriecas”), suundub Ikstena edasi hoopis triviaalsete lugudeni „elust”. Ikstena kirjutuslaad on muutunud lakooniliseks ja kohati teravaks, vaimustavad metafoorivolangid on asendunud eraldiseisvate, kitsilt jagatud metafooridega, mis toimivad nagu naasklitorge. Ka lugude süžeed ei hõlju enam metafoorsetes sfäärides, vaid on pigem maalähedased, kohati isegi primitiivsed - muidugi tagab autori meisterlikkus selle, et lugu ise pole ligilähedaseltki maalähedane ega primitiivne. Kriitika kirjutas, et Ikstena on leidnud „kuldse kesktee ära tüüdanud konservatismi ja kunstliku avangardi vahel”. Üks Ikstena süngemaid ja traagilisemaid lugusid on „Amarüllid” („Amarillli”): kaks vanainimest 
on teineteise elu hävitanud, sealjuures nõnda põhjalikult, et olemist tuntakse ikkena ja surma oodatakse kui vabanemist. Milline aeg parasjagu ka ei oleks, pole süüdi ajaloohoobid, vaid inimesed ise. Sellist süžeed võib kujutada mitmeti - nii melodraama, moraaliloo, anekdoodi kui ka eksistentsiaalse draamana. Ikstena on valinud viimase variandi. Selline „olemise talumatu raskus” on tuntav ka teistes lugudes. „Vaikelu surmaga” („Klusā daba ar nāvi”): naine, kelle lapsepõlves neljakümnendatel aastatel pääses tema ema äärmiselt rasketes oludes sõna otseses mõttes surmast, püüab kogu elu teha enesetappu ilma tõelise põhjuseta - justkui tahaks tagasi maksta mingit metafüüsilist võlga. Mis on see võlg ja miks enesetapukatsete seeria alguse saab - see jääb väljapoole loo piire. Selline on elu, sellised on elulood, ja teha pole midagi. „Kunn” („Naǵe”): suurepärane looke sellest, kuidas sant naine peaaegu leiab eluõnne möödasõitvaid meesterahvaid lohutades ja rahuldades, kui temast saab juhuslikult maanteetüdruk, ja millise kurva lõpuni see kõik viib.

Läti emigratsioon, enamjaolt Inglismaale ja Iirimaale, on juba alates XX sajandi lõpust aktuaalne ja tundlik teema, sestap pole juhus, et see peegeldub ka kirjanduses. Esimesena puudutab seda teemat Laima Muktupāvela romaanis „Šampinjonu derība” („Šampinjonitestament”, 2002), milles on peamiselt autori enda kogemustele tuginedes kirjeldatud lätlanna läbielamisi Iirimaal üheskoos Iiri Läti-müütide ja toiduretseptidega, mis süžeega elegantselt kokku kõlavad. Emigratsiooni sotsiaalsed ja psühholoogilised probleemid on tähelepanu keskpunktis ka prosaisti Andra Manfelde (1973) osaliselt dokumentaalses romaanis „Dzimtenīte” („Piiritus”, 2012). Kõige ekstravagantsema ja iroonilisema versiooni emigrantide elust on avaldanud Vilis Lāeittis (1975; autori pseudonüüm mängib irooniliselt läti kirjanduse ja sotsrealismi klassiku Vilis Lācise nimega) - romaani „Stroika ar skatu uz Londonu” („Ehitusplats vaatega Londonile”, 2010). Läti kirjanduses puudub õnnetul kombel juba teab mitmendat aastat normaalne lugemisvara. Leidub teoseid, mis sihivad kõrgemale, mõnikord õigusega, või siis hoopis vastupidi - tekste, mis isegi ei sihi, vaid on juba sündinud prügikasti. Keskel valitseb tühjus. Lācītis püüab seda territooriumi täita. Süžee on ligikaudu säärane: on päris XXI sajandi algus, tee Lätist Inglismaale on juba korralikult sisse tallatud ja seda teed pidi asub õnne ja raha otsima ka poolküps moosekant Vilis Lācītis. Ligi poole romaanist moodustavad tema kogemuste kajastused vaheldumisi proletaarlikult räämas, boheemlike pildikestega võõrtöölistest, mida täiendavad autori /kangelase mõtisklused pisut üldisemate teemade üle. Välgatab ja haihtub olematusse palju värvikaid tüüpe, kellest mitmed hiljem kohusetundlikult naasevad, et aidata süžeeotsi tihedamalt kokku tõmmata. Irooniline suhtumine kõigesse ja kõigisse lubab teravmeelselt ja elavalt kirjeldada tegelikult küllap üsna hirmsat ja nüristavat argipäevarutiini. Iroonia päästab ka sellistel juhtudel, kui kasutatakse mõnd habemega nalja, kuna kui muu ei aita, võib ironiseerida nii nalja kui ka habeme üle. Romaani suurim pluss: „Ehitusplats vaatega Londonile” on üks vähestest tekstidest, mis peegeldab tegelikku keelekuju kõigi kõnekeelsuste ja barbarismidega. See on tõepoolest suur kunst - reaalset kõnekeelt mitte pimedalt kopeerida, vaid luua keelekeskkond, mis poleks kaotanud seost reaalsusega ja vastaks täpselt nii kirjeldatavale keskkonnale kui ka tegelastele. Põhimõtteliselt loob iga autor oma keele, sealjuures pole seda keelt võimalik teadlikult konstrueerida, kuna siis saaks sellest vaevu surnultsündinud esperanto või midagi taolist, ja keele loomulikkus sõltub ainult sellistest eeter- 
likest asjadest nagu talent ja intuitsioon. Siinkohal tuleks veel kord rõhutada sõna „tundub” - kunst on alati kunstlik ja ilustatud, kuid kõrgeim pilotaaž on sisendada lugejaile, et see kunstlikkus on loomulik. Lācitisel õnnestub see harukordselt hästi. Hooplev ja irooniline žargoon, mida elavdavad toredalt küünilised kaunistused, ei tundu mitte ainult ise väga elulähedane, vaid elavdab ka süžeed, põimudes sõnamängu või keelelise vääritimõistmise kujul siin-seal romaani vigurlike ja lõbusate mikroepisoodidena. Romaani teises osas hakkavad pisisündmuste tihnikus vähehaaval välja joonistuma kesksete süžeeliinide piirjooned. Idee on selge - toetuda mõlema jalaga argipäeva, et kogu romaani konstruktsioon viimaks suurejoonelises lõppmängus õhku lasta. Valitud on piisavalt mõjus aines märgatava groteskilisandiga: ühel pool nõdrameelsed leedu sektandid, kes ootavad maailmalõppu, teisel pool lätlased, kes valmistavad hankat, ${ }^{6}$ et pääseda kiire, suure ja kerge raha juurde. Selge on, et kahe säärase ühitamatu asja kokkupuutel vallandub plahvatus. Ja plahvatus tõepoolest toimub, hanka keetmisprotsessi ajal lahvatavad leekidesse lahusti aurud, maailma lõpp on kohe-kohe kohal, isegi Jeesus kui mitte ei roni maa peale, siis vähemasti näitab taevast oma habetunud näolappi.

Lugedes Gundars Ignatsi (1981) debüütkogu „Bez jakas” („Ilma jakita”, 2009), haarab teatud naiivne imestus: „Ignatsi proosas pole ju midagi! Kuid miks mulle näib, et midagi selles on, ja kui ka on, mis see õigupoolest olla võiks?” Näiteks pretensioonitu, tüüpiliselt ignatsilik lugu „Mu tüdruk joonistab inimesi” („Mana meitene zìmē cilvēcinuus”): kutt jookseb postkontorisse saadetise järele, et see kindlasti tolsamal õhtul oma tütarlapsele toimetada. Peaaegu hilineb, kuid siiski jõuab ... Ja ongi kõik, kui mitte arvestada mööda sõites läbi auto aknaklaasi nähtud avariid - maanteel hukkub mootorrattur - ja poest pelmeenide ning paari pudeli õlle ostmist. Pilk libiseb pikkamisi üle juhtunu, registreerides iga pisiasja, ekslemata ei metafoorsetesse kaugustesse ega ka eksistentsiaalsetesse sügavikesse. Absoluutne lihtsus - nii absoluutne, et sellest saab väärtus iseenesest. Ignatsi proosale on omane aeglane jutustamine ja stiil, mille kriitika põhjendatult ristis „fotograafiliseks”: väga üksikasjalised kirjeldused ja peaaegu maniakaalne täpsus. Milleks sellist täpsust tarvis on? Autor keskendub asjade ja sündmuste kirjeldamisele, nii et see tegevus omandab kõrgeima kvaliteedi ja saabki, kui nii võib öelda, loo süžeeks. Omapärane alkeemia - kõige olulisem on loos just see pisidetailidega küllastatud kirjeldus; tegevus ja kõik muu, mida tavaliselt proosast otsitakse, taandub taustale, seevastu esiplaanile kerkib miski, millele on raske nime leida. Ignatsi kirjutuslaad meenutab puurimist proosa sügavikesse, püüdes kätte saada proosa olemust, et jagada see koostisosadeks ja mõista, mis elementidest proosa koosneb. Kõik mitmekülgsed proosavõimalused redutseeritakse ühele elemendile, mis see-eest on viidud täiuseni. Lugu kujuneb ilma „kõrgema eesmärgita”, kuid seetõttu saab kõrgeimaks eesmärgiks jutustamise protsess ise - tekst on sisuliselt tähenduseta. Mis tahes kirjandustekstist on tavaliselt kombeks otsida allteksti, pealisteksti, tekstitagust - igal juhul mitte teksti enda - mõtet, seevastu Ignats näitab „ainult” teksti ilma nende segavate kihistusteta ja küsib demonstratiivselt, peaaegu naiivselt: „Kas see on veel proosa? Ja kui ma võtaksin ära veel selle ja tolle, siis - kas jääks alles proosa?” Põhimõtteliselt tuleb Ignats oma lugudes jälle tagasi küsimuse juurde, mis on

\footnotetext{
${ }^{6}$ Hanka - oopiumimooni segu. (Tõlkija märkus.)
} 
kirjanduse aluste alus: mis loom see õieti on, mida kutsutakse kirjanduseks? Sellele küsimusele vastust otsides uitasid prosaistid üheksakümnendail, nagu juba öeldud, metafoorsetesse kaugustesse ja eksistentsiaalsetesse sügavikesse. Ignats otsib teist teed, mis - vähemasti praeguse proosa kontekstis - tundub väga lootustandev, kuna on täiesti teistsugune.

Jānis Joṇevsi (snd 1980) debüütromaan „Jelgava 94” tundub esmapilgul vähemasti osaliselt kuuluvat proosakoolkonda, mis käsitleb erinevate subkultuuride, kontrakultuuride või äärealade eripärasid (esimene sellise suundumusega proosa esindaja läti kirjanduses). Autor kirjeldab omaenda kogemusele toetudes metal-muusika ja metallistide subkultuuri algusaegu Lätis üheksakümnendail aastail, valides alguspunktiks 1994. aasta 8. aprilli, mil ansambli Nirvana liider Kurt Cobain sooritas enesetapu. Cobaini teelesaadetud kuul tabab ka romaani peakangelase aju, keerates Jānise mõtlemise õigesse suunda. Prillidega nooruk, läbinisti korralik ja aus koolipoiss, muudab äkitselt orientatsiooni ja temast saab tõsiusklik metallist, kes romaani edasistes sündmustes sukeldub sügavale heavy-, black-, death-, doom-, thrash-ja muudesse säärastesse substantsidesse ja nende kombinatsioonidesse. Sellele muutusele on pühendatud romaani esimene osa „Lask” („̌S̄aviens”). Teises osas „Kuu” („Mēness”) on eepilises mastaabis kirjeldatud metallisti päevi ja öid. Kolmandas osas „Apokalüpsise järel” („Pēc apokalipses”) on Jānis juba kolmekümne ringis, ta on metal-mähkmetest välja kasvanud, prillid siiski endiselt ninal, kuid nüüd on need Diorid, ja ka veini joob ta nüüd snooblikult kvaliteetset.

Süžee poolest on "Jelgava 94" teismeliste rumalate tegevuste kroonika: romaani peakangelased Jānis, Nāve (tlk Surm), Zombis (tlk Zombi) ja ülejäänud seltskond elavad ilma aadete ja sügavate mõteteta - alatasa otsivad nad, kust tasuta juua saada, kuidas tasuta kontserdile pääseda, kuidas tasuta Riiga sõita, kuidas tasuta bändi teha, ja nii edasi, 250 lehekülje ja paari aasta jagu. Romaan on kirjutatud kolmekümneaastase Jānise vaatepunktist, sestap on autoril vabadus manööverdamiseks ja ta võib asjale lisada nii irooniat kui eneseirooniat. Vahel sähvatab ka mõni eksistentsiaalne refleksioon kontrakultuuri klassikute vaimus: „me vihkasime edukaid ja imetlesime viletsaid”, „mitte olla kruvi,” „välja murda argipäevast, tavapärasusest” ja muu säärane, kuigi romaanis tervikuna puudub kontrakultuuri paatos - kõik need mõtisklused teistsugususest, lõppematud vestlused metal-bändi loomisest ja maailma raputamisest jäävad tühja loba tasemele. "Jelgava 94 ” on pigem romantiline lugemispala, kuigi ilma „noorsooproosale” omase imala „aga vanasti oli muru rohelisem"-toonita. Absoluutselt realistlik, peente detailidega pealiskiht koos noorukite rumalavõitu tegevusega varjab täiesti arvestatavat mõttesügavust. Mängureeglid kehtestatakse juba esimestel lehekülgedel: Cobain tulistab Ameerikas ja tabab Jānist Lätis. Teisisõnu, autor hõlmab teksti võõrad inimesed, kauged paigad, teised ajad ja, mis pole vähem tähtis, teised raamatud. Selliseid intertekstuaalseid hüppeid ei esine liialt sageli, kuid siiski piisavalt regulaarselt, et muidu amorfne ja ülemäära lineaarne jutustus muutuks kompaktseks ja ruumiliseks. Kohati ristub kaasaja metal-üritustega ootamatult sajanditetagune minevik - kas või sel lihtsal põhjusel, et metallistidel on tavaks veeta aega pika ajalooga hoonetes ja romaanis visandatakse põgusalt see ajalugu. Teinekord jälle leiab Jānis ühest Läti väikelinnast Vonneguti „universumi urruaugu”. Paroodiaobjektina vilksatab korduvalt Salinger. Metallistide öiste tegevuste kulgu suunab Shakespeare, nii et meelde tuleb „Suveöö une- 
nägu”. Teise osa lõpupeatükis on selgelt tunda Bulgakovi kohalolu. Intertekstuaalse meelelahutuse kulminatsioon saabub ühel kontserdil: läti metal-bändi Huskvarn tegevus äratab ellu surnud küti Esimesest maailmasõjast, kelle täägitorge Skyforgeri ${ }^{7}$ hilisema solisti Pēteris Kvetkovskise südamesse innustab bändi looma küttidele pühendatud laulude tsüklit, mis hiljem Mustas Reedes ${ }^{8}$ lavalt kõlab. Nüüdisaegses kirjanduses on intertekstuaalsus iseenesestmõistetav ning romaanis „Jelgava 94” toimib see suurepäraselt, ühest küljest põhisüžeele vastandudes, teisalt püüdes seda tõsta metafoorsetesse kõrgustesse.

Mõistagi pole siinses kirjatükis käsitetud kõiki tähelepanu väärivaid prosaiste. On olemas veel Māris Bērziņš, kes pälvis lugejate tähelepanu tsükliga „Gūtenmorgens” („Guten Morgen”, mis tähistab nii tekstitsüklit kui ka žanri). Guten Morgen on pisut naljakas, pisut absurdne, pisut veider, kuid igal juhul sümpaatne tüüp, kelle otsustes ja tegudes on paradoksaalsel kombel sageli tuntav terve mõistuse hääl, "gutenmorgenid” omakorda on lühikesed, mõnikord vaid poole lehekülje pikkused tekstid, milles on kirjeldatud juhtumeid Guten Morgeni elust. Virvendavad lugematud paradoksid, sõnad pusklevad omavahel, jõudes alatasa täieliku mõttetuse ummikusse, kust väljapääsu leiab kui mitte naeru, siis vähemasti heatahtliku naeratuse abiga. Erinevalt enamikust absurdistidest, kel on tavaks masohhistliku rõõmuga sukelduda olemise lootusetusse, on Bērziņši grotesk ja iroonia alati helge ja südamlik. Sarnastes toonides on ka tema romaan „Titāna skrūves” („Titaankruvid”, 2011) - paroodiline melodraama või ehk lihtsalt kaasajale tavatult õnneliku lõpuga armulugu. Romaanis „Sveiks, Dzintar Mihail!” („Tere, Dzintars Mihails!”, 2013) lubab autor jällegi endal olla raevukalt moraliseeriv, kroonides kaunis primitiivse süžee lõpuga, kus apokalüptilises ilutulestikus ühinevad põrgu ja paradiis. On olemas luuletaja ja prosaist Maira Asare, kelle proosateos „Sieviešu zona” („Naiste tsoon”, 2009) kõneleb dramaatilistest läbielamistest vanglas, kuhu autor ise sattus narkootikumidega äritsemise tõttu. Naiste tsooni kohta kirjutab autor, et „seda paika tuleks nimetada pigem absurdseks ja mõttetuks, mitte aga karmiks ja halastamatuks". Ajaväline absurdieksistents ei sobi klassikaliselt realistliku kirjutuslaadi põhimõtetega kokku, aga mis teha, kui absurdist on saanud reaalsus. Ei jää muud üle, kui luua isiklik, peaaegu unikaalne kirjutuslaad, mis on võimeline adekvaatselt kirjeldama niisama unikaalset kogemust. On olemas prosaist Pauls Bankovskis, kes omal ajal kirjutas postmodernistliku, kuigi faktitäpse, seiklusromaani vaimus pastiši „Misters Latvija” („Mister Läti”, 2002) ning terava nõukogude aja teemalise romaani „Čeka, bumba un rokenrols” („Tšekaa, pomm ja rock'n'roll”, 2002). Seni viimases romaanis „Viens ar Kantu” („Üksi Kantiga”, 2012) on tähelepanu keskmes harukordne isiksus - Otto Rolavs, kes nõukogude ajal raamatukogus töötades järjepidevalt tõlkis Kanti töid, ise teadvustades, et neid avaldada pole võimalik. Paradoksaalsel kombel ulatub Rolavsi tõlgete kuma tänapäeva ja seostub suurima plagiaadiskandaaliga Läti ajaloos. On olemas Juris Zvirgzdiṇš (snd 1941), kelle proosa näitab, et autor võib üle seitsmekümne aasta vanusena olla hullumeelsem, paradoksaalsem ja ekstravagantsem kui paljud kahe- ja kolmekümneaastased. On olemas Margarita Perveṇecka (snd 1976), kelle romaan „Gaetāno Krematoss” („Gaetano Krematos”, 2011) ennustab, et on või-

\footnotetext{
${ }^{7}$ Skyforger on läti folk-metal ansambel. (Tõlkija märkus.)

${ }^{8}$ Must Reede on reaalne Riias asuv klubi. (Tõlkija märkus.)
} 
malik ületada ka Einfeldsi mahamärgitud kirjanduspiire. On olemas Kristīne Ulberga, kes pärast mõne noorteraamatu avaldamist on välja andnud romaani „Zạ̦ā vārna” („Roheline vares”, 2012), milles autor sukeldub metafoorsetesse aruteludesse vabaduse/vabadusetuse teemal. Ja on olemas palju teisi äärmiselt erinevaid. Järeldus on ilmselge: kuni kirjandus muutub ja heitleb iseendaga, seni on ta ka olemas.

Lätikeelsest käsikirjast tõlkinud MERLE MADISSON

\section{A short guide to Latvian prose}

Keywords: Latvian literature, contemporary literature, prose, overview

The article gives a brief overview of the developments in $21^{\text {st }}$-century Latvian prose and takes a closer look at nine authors. In comparison with the roaring nineties the Latvian prose has stabilized over the recent decade. Every author has found their own poetic voice and those different poetics coexist in peace, without revealing any too clear divisions.

In this bland context, Aivars Kḷavis comes up with a surprise, as his extensive historical tetralogy Vinpus vārtiem („On the Other Side of the Gates”) demonstrates quite a liberal attitude to the traditional conception of Latvian history. The three parts of Gundega Repše's Smagais metāls („Heavy Metal”) provide a mythologized view of the life of three women and their fight against time. Inga Ābele Paisums („High Tide”) is a gloomy novel in the spirit of classical modernism, also based on mythology, this time the Greek one. The dreamlike reality of Nora Ikstena combines lacy metaphors with colourful characters and loci. Inga Žolude's debut novel Silta zeme („Warm Earth”) takes the reader to an unrealistic scenery inhabited by some infantile and asocial creatures for whom the end of the tunnel means nothing but darkness. Jānis Einfelds is a professional provoker and transgressor, whose oeuvre offers some extremely poetic visions as well as post-apocalyptic worlds. The short stories by Gundars Ignats, however, cultivate absolute simplicity as style. Emigre literature stands a little apart: the novel Stroika ar skatu uz Londonu („Construction Site with a View of London”) by Vilis Lācītis, for example, describes the life of a Latvian musician in England, while Jānis Jonnevs investigates the peculiarities of various sub- and countercultures and peripheries.

Guntis Berelis (b. 1961), freelance writer and literary critic, berelis@gmail.com 